\title{
Increased insulin resistance compounded by reduced insulin sensitivity drives the "Fat Aussie" (Alms 1 foz/foz) model of Alström syndrome towards obesity and type 2 diabetes mellitus
}

\author{
D Girard*, N Petrovsky
}

From First International Cilia in Development and Disease Scientific Conference (2012)

London, UK. 16-18 May 2012

\section{Background}

The Fat Aussie mouse carries a spontaneous mutation $(f o z)$ resulting in a premature stop codon in exon 8 of the Alms 1 gene and is a model for Alström syndrome. From 60 days of age onwards Alms1foz/foz mice exhibit a strong metabolic phenotype leading to severe obesity and type 2 diabetes mellitus (T2DM).

\section{Objective}

Investigate whether peripheral insulin resistance or a beta-cell insulin secretory defect comes first in young, non-obese pre-diabetic Alms1foz/foz mice.

\section{Methods}

Insulin tolerance tests (ITT), glucose tolerance tests (GTT), fasting and post-challenge serum insulin levels and HOMA-IR score determination were performed in age and sex-matched young lean Alms1foz/foz mice and wildtype littermates.

\section{Results}

When compared to wildtype mice, young Alms1foz/foz mice had a significantly reduced response to insulin during ITT while no differences were observed in glucose and endogenous insulin levels during GTT. Male but not female Alms 1 foz/foz mice had significantly higher fasting hyperinsulinemia and HOMA-IR scores compared to wildtype littermates.

\footnotetext{
* Correspondence: dorothee.girard@health.sa.gov.au
} Flinders University, Adelaide, Australia

(c) 2012 Girard and Petrovsky; licensee BioMed Central Ltd. This is an Open Access article distributed under the terms of the Creative Commons Attribution License (http://creativecommons.org/licenses/by/2.0), which permits unrestricted use, distribution, and reproduction in any medium, provided the original work is properly cited.

\section{Conclusions}

These data indicate that insulin resistance precedes obesity in young Alms1foz/foz mice at a time that beta-cell function isn't affected. This suggests that early peripheral insulin resistance is an inherent primary consequence of the Alms 1foz/foz mutation and may thereby drive the subsequent metabolic complications in this model.

Published: 16 November 2012

doi:10.1186/2046-2530-1-S1-P86

Cite this article as: Girard and Petrovsky: Increased insulin resistance compounded by reduced insulin sensitivity drives the "Fat Aussie" (Alms1foz/foz) model of Alström syndrome towards obesity and type 2 diabetes mellitus. Cilia 2012 1(Suppl 1):P86.
Submit your next manuscript to BioMed Central and take full advantage of:

- Convenient online submission

- Thorough peer review

- No space constraints or color figure charges

- Immediate publication on acceptance

- Inclusion in PubMed, CAS, Scopus and Google Scholar

- Research which is freely available for redistribution

Submit your manuscript at www.biomedcentral.com/submit
( Biomed Central 